\title{
GENDER IDENTITY AND EMOTIONS IN EMAIL SPAM
}

\section{Identidad de género y emociones en los correos de spam}

\author{
Simone Belli*; Miriam Jiménez** \\ * Yachay Tech (Ecuador); ** Universidad Autónoma de Madrid (Spain) \\ sbelli@yachaytech.edu.ec; miriam.jimenez@uam.es
}

\section{Keywords}

Nigerian scam

emails

Deception

Fear

Gender

stereotypes

Fairy tales

\section{Palabras clave}

Emails del timo

nigeriano

Miedo

Engaño

Estereotipos de género

Cuentos de hadas

\begin{abstract}
$\underline{\text { Abstract }}$
The main aim of this paper is to present briefly how "fear" contributes to the construction of deception through the abovementioned narratives. We will take into account not only the linguistic and psychological elements used to cause real fears in their recipients, but also the fake and real fears their senders may have, adding examples to our findings. We will pay specific attention to the influence of gender stereotypes in certain narratives where the senders' gender/ed identity was faked, and to the connection between spam e-mails and fairytales. The aim of this paper is to find out the relation between spam e-mails, fairytales and gender stereotypes regarding fear. Our analysis suggests a parallelism between the reproduction of gender stereotypes in the new communication tools and the same stereotypes found in traditional fairytales. We will focus on how fear connects spam and fairytales, and how this parallelism and the gender stereotypes found in both kinds of texts can take part in the linguistic mechanisms used by spammers to make their stories believable.
\end{abstract}

\section{Resumen}

El objetivo principal de este trabajo es presentar cómo el "miedo" contribuye a la construcción de engaño a través de los correos spam. Vamos a tener en cuenta no sólo los elementos lingüísticos y psicológicos utilizados para provocar miedos reales en sus destinatarios, sino también el miedo que sus remitentes pueden tener, añadiendo ejemplos textuales. Vamos a prestar especial atención a la influencia de los estereotipos de género en ciertas narraciones donde la falsa identidad de género de los remitentes se relaciona con los cuentos de hadas y los correos de spam. El objetivo de este trabajo es conocer la relación entre los correos spam, cuentos de hadas y los estereotipos de género en relación con el miedo. Nuestro análisis sugiere un paralelismo entre la re-producción de estereotipos de género en las nuevas herramientas de comunicación y los mismos estereotipos que se encuentran en los cuentos de hadas tradicionales. Nos centraremos en cómo el miedo conecta spam y cuentos de hadas, y cómo este paralelismo y los estereotipos de género que se encuentran en ambos tipos de textos pueden participar en los mecanismos lingüísticos utilizados por los spammers para hacer que sus historias sean creíbles.

Belli, S. y Jiménez, M., 2015, "Gender identity and emotions in email spam", en Papeles del CEIC, vol. 2015/2, no 129, CEIC (Centro de Estudios sobre la Identidad Colectiva), Universidad del País Vasco, http://dx.doi.org/10.1387/pceic.13194 


\section{INTRODUCTION}

Internet users know it: new technologies have brought new communication tools, which are fast, handy and cheap. With just couple of clicks, Internet users are able to send messages to several people at the same time. If we add the possibility of remaining anonymous, we are creating a wonderful scenario for spammers.

Spammers are people who send "spam e-mails", the ones you will certainly find in your electronic mailbox. You will recognise them easily: most of them try to make a product or service known, but also to deceive people in order to get, most of the times, their money -that is, to commit fraud-. Spammers concoct fake identities, non-existent people with false stories that appeal to receivers' emotions and qualities or faults, such as empathy, mercy and greed.

Our analysis suggests not only a parallelism between the re-production of gender stereotypes in both the new communication tools and the same stereotypes found in traditional fairy tales, but also a clear similarity between the use of fear in spam e-mails and fairy tales, depending on the gender identities the author has adopted. We will focus then on how fear connects spam and fairy tales, and how this parallelism and the gender stereotypes found in both kinds of texts can take part in the linguistic mechanisms used by spammers to make their stories believable.

In order too present briefly how "fear" contributes to the construction of deception through the abovementioned narratives, we will take into account not only the linguistic and psychological elements used to cause real fears in their recipients, but also the fake and real fears their senders may have, adding examples to our findings. We will pay specific attention to the influence of gender stereotypes in these narratives, where the senders' gender/ed identity was - or could have been - faked, and to the connection between them and fairy tales.

\section{WHAT IS A SPAM E-MAIL?}

Our bibliographical review has been difficult because of the limited literature on the electronic mails issue and, specifically, on these "spam e-mails", given the scarce attention that has been paid to them from a linguistic-scientific point of view, even though Internet provides researchers with a wide number of samples and individuals, subjects of study - and, at the same time, deceitful e-mail senders with a huge possible audience. Mainly, works on spam have focused on the narrative style - for the development of tools that can detect spam in our e-mail inbox - or on fraudulent aspects. 
In the social imagery, and apparently supported by several researches (Whitty \& Joinson, 2009), persists the idea that people with individual tendencies communicates more easily through the Internet. This notion has an influence on the high credibility given to the deceitful e-mails by the recipient, but also on the sender, who takes advantage of the anonymity provided by the Internet to create his/her lonely (and helpless, in the female case) characters.

Whitty and Joinson's research (2009) have demonstrated that the predominantly male groups on the Internet tend to use a language oriented to facts, to personal promotion and even insults, while the predominantly female ones tend to suggest ideas, express doubts and, above all, use methods for preventing tensions and conflicts.

Most of the times, spam e-mails' final objective is committing fraud, that is, deceiving the recipient through a fraudulent activity. This goal is also pursued by traditional Nigerian letters. The message offered by this kind of spam is "get rich quick" (Cukier, Nesselroth y Cody, 2007). According to the authors, this spam genre uses rich narrative appeals to strong emotions like greed, guilt, lust and fear, and invokes archetypal myths of windfall fortunes in an effort to elicit behaviours which, for the most part, are counter-factual. Regarding narrative styles, it is difficult to find studies in which we can observe the way in which spam e-mails are structured and justified, except maybe for the work of Cukier, Nesselroth and Cody (2007) on "genre and narrative in Nigerian Letters".

Regarding fraudulent activities, spam has also been studied for anonymity and hidden identity reasons. Susan Herring (in Holmes \& Meyerhoff, 2003) points out that Internet users can choose to disguise or hide their identities, but they can also choose not to, showing their attachment to certain groups. Identity concealment is a widespread phenomenon in the Internet. Concealing an identity means hiding oneself behind an invented or borrowed identity. In several cases, such as that of the Anonymous group, it is used to create a certain effect in the society, and in some others, is to deceive or act in a fraudulent way.

\section{DECEPTION AND THE INTERNET}

There are mainly two types of deception in electronic mails: the sender's identity-based one and the content-based one. In spam e-mails, we can observe both of them. The appearance of deception and fraud on the Internet brings another factor that takes part in this subjectivization construction, that is, fear. Fear is one of the main emotions appearing in these e-mails to contribute to deception, as we will see in our analysis.

Many researchers concentrate on the ways in which our identities are narrative in nature (Bruner, 1990) and how our life stories contribute to 
or detract from the functionality and resiliency of those identities (McAdams, 1993; Koenig, Willer and Kranstuber, 2011).

There are some emblematic cases in our society that show us how stealing a virtual social identity has its effects on real life. A stolen "voice" can be used to transform a lie into news. An example of this is the case of Tommaso De Benedetti, who impersonated Umberto Eco in Twitter to announce the false death of Gabriel Garcia Marquez, in order to show how deceiving (even journalists, if they do not check the veracity of some news) is possible and very easy thanks to the new technologies.

Umberto Eco (2012) declares that there is a kind of hidden and anonymous communication being spread on the Internet. Society knows that the mutual commitment for the truth is essential, and each one of us would be lost if this disappears. But, according to Eco, there is a secret message on the Internet that is getting users accustomed to not trusting and being afraid. Nevertheless, the apparent blessings that computer-mediated transactions bring may be countered by fear and anxiety, above all, regarding virtual economic transactions, where users do not know who is on the other side or whether their identity is true. Transactions characterized as faceless and intangible are plagued with a host of concerns, which could result in people's reluctance to engage in any form of online transaction. The wider acceptance of online transactions, despite the perceived risks involved, depend not only on the estimated benefits they offer but also on people's trust in online transactions, in the technology used for the transactions, and in organizations as the other parties in the transactions (Beldad, de Jong, Steehouder, 2010).

For this reason, we always wonder who is on the other side when we want to carry out certain transactions. Fear of this Other deceiving us depends on different variables. It is not within the limits of this work to go into these variables in any depth, since they are related not only with our fears in the online world, but also to our fears on the offline world, that is, to all our previous experiences that influence our perception on being afraid and not trusting unknown people. Fear appears in two different contexts in the same time, online world and offline world, and there is one interesting question we would like to answer in future papers in relation to this: is there any belief in the social imagery about close people -those we have some intimacy with- not deceiving us? That is, is intimacy considered a certainty of non-deceiving intentions for us?

Online fear is also generated by the risk of an online interaction where an economic transaction could happen. This transaction has to do with risk, costs, complexity and, of course, fear. This perception of fear 
exposes the subject to a vulnerability and expectation related to the behaviour of the sender, applied to the online relation and exchange. Feelings of obligation, loss of control, and fear are drawbacks to offline social support (Albrecht, Burleson and Goldsmith, 1994), which online support can solve. According to Tu and Mclsacc (2002), without the context of online interaction, the social presence between two subjects can be seen as a series of sensations, perceptions and reactions to the fact of being connected through the computer-mediated communication to another intellectual entity in a text-based encounter. For this reason, a para-language (based on emoticons, different communication styles, task types and privacy) is used many times in this kind of communication (Tu, 2002b). Emotions are the means through which deception is produced and, for this reason, it is extremely important to study them as a mechanism.

\section{BED-TIME TALES? PARALLELISM WITH FAIRY TALES}

"The fact of storytelling hints at a fundamental human unease, hint at human imperfection. Where there is perfection there is no story to tell." Ben Okri

(1997, p.112)

Relating fairy tales and Discourse Analysis is not a new issue: George Lakoff did it in 1992, while trying to show how war had been justified by means of metaphors. He analysed the metaphors used and how fairy tales were a perfect interpretation framework for political discourse, seeking for the identification of one country with the villain and the other one with the victim, so the third country could arise as a saviour, legitimizing its discourse and making it acceptable for a general audience (Lakoff, 1992).

Fairy tales are, as we already said, part of the collective consciousness. Because we are fundamentally storytelling creatures, homo narrans (Fisher, 1987), or naïve scientists (Heider, 1958). We are compelled, as Koenig Willer and Kranstuber (2011) suggest, to make sense of our relationships by telling stories about them to ourselves. Some authors have studied their form and their psychological implications but, their true force resides in their stereotypes staying in the adult mind. They create interpretation frameworks that are constantly evoked and activated by certain narratives and metaphorical discourses. This framework provides the narrative with an important element: credibility, veracity, and ultimately, legitimization of discourses and actions, as we will see. Fairy tales are, then, not only mere representations of what existed in an old collective mind, but also carriers of stereotypes and instruments for their reproduction in a digital intercultural communication context. 
Propp's morphological studies (1968) on Russian tales are very useful for describing the structure of these narratives: the attributes and functions, that is, the characters and their situations, as well as certain linguistic elements, are intimately related to the discursive construction of gender/ed identity (especially with agency and passivity) and gender stereotypes. For Propp (1968:38), fairy tales structure seems clear: there is an initial situation, the members of the family are listed and the future hero is simply introduced by his name or the description of his condition. After this initial situation, a series of events happen and, after that, the end comes, generally with a punishment for aggressors or villains and rewards for the hero.

Spam e-mails tell a story with good and bad characters, heroes, monsters and murderers included. Myth is the most powerful device in the persuasive nature of Nigerian letters. Apart from the direct appeal to emotions - primarily greed and pathos -they also, at a fundamental level, apply narratives which invoke well known cultural myths including the rags to riches story - as well as other familiar motifs (the wealthy widow, the lost treasure trove, the imprisoned woman, the redistribution of pilfered money, the victim of cruelty, the victim of society, etc.). These mythical narratives allow the victim to play mythical roles: the rescuer, the lucky finder of lost treasure, the benevolent hero, the sympathizer, the good thief. Essentially, recipients want to believe, in spite of the fairly obvious questions, that they have been selected - they have finally found their pot of gold, fairy godmother, damsel in distress etc. The need to feel special, lucky, or heroic - a willing of being famous, rewarded and recognized - is fundamental to the human experience. The perpetrators of these fraudulent schemes ensnare their victims by manipulating these core desires through the narrative genre. Most letters are an attempt to appeal to multiple emotions and layer catastrophe (civilian massacres) upon political unrest, sexism, discrimination, and, ironically, systemic corruption.

Telling stories of difficult situations helps people understand what happened, gain control over the events, and achieve a sense of catharsis that represent a formidable coping resource (Weber, Harvey and Stanley, 1987). One of the primary benefits of narrating stories is the ability to cope with their dark and shadowy sides (Koenig, Willer and Kranstuber, 2011). Making sense of spam emails become concrete when we think of it in terms of telling stories about various relational events, stages, turning points, and problems. For Koenig, Willer and Kranstuber (2011), people tend to celebrate stories of relational beginnings, family triumphs, funny and charming milestones, and significant positive turning points. At the same time, people tell stories as they grapple with 
the complexities of relational maintenance, discord, transgressions, and relational endings.

\section{OGRES DISGUISED AS PRINCESSES. HOW DO GENDER STEREOTYPES WORK?}

One important question upon which our work is built is the following one: how are gender stereotypes in spam and in fairy tales related? In our spam analysis, we were shocked by the use of strategies typical from fairy tales that almost everyone has read during his/her childhood.

The princess that has escaped a burning castle, while her father was killed by a ferocious and hungry ogre, for example, is very similar to the first e-mail we presented in this essay. Our princess, by means of a gender stereotype, looks for her blue prince, the one that could save her from evilness and tragedy.

There are many variants on the following plots which build upon archetypal myths: virtually every Nigerian letter invokes the universal story of rags to riches with the promise of easy money or windfall fortune or Pot of Gold. This story is so pervasive, across cultures, and has such a strong appeal to our hopes and aspirations that it leads people to behave irrationally and engage in a scheme that is incredulous. The writer is seeking a business partner: usually, there is a situation which has led to a large amount of money in a bank account and, for a wide range of reasons, the writer needs your assistance to access the money in order to circumvent local restrictions or to pose as an heir to the fortune. The writer may be a banker or the personal assistant to a despot such as Charles Taylor. The recipient is asked to claim to be next of kin to get the funds released. Or, the writer has found a treasure trove - illgotten gains from a dictator, treasure from the deposed king, or a deceased and heirless diplomat - and wants your help to access them. Often, the main character, which is the principal source of the money, draws on motifs from folklore and fairy tales. These letters offer an opportunity for the reader to become a hero and rescue the hapless maiden.

The letters also use a range of rhetorical and stylistic techniques intended to reinforce intimacy, proximity and promote trust or in some cases, a feeling of superiority. Apart from the obvious appeal to emotions - primarily greed but also pathos - they also, at a fundamental level, use narratives which invoke well known cultural myths. Essentially, recipients want to believe, in spite of the fairly obvious counter-factual evidence, that they have been selected - they have finally made their fortune. In this way the Nigerian letters invoke powerful myths that permeate many different cultures. 
The rags to riches stories are deeply embedded in our psyche in fairy tales - the story of Cinderella who hooks her prince with the help of a fairy godmother, the story of the pot of gold at the end of the rainbow, the buried treasure, or of Robin Hood, who when driven from his land by evil Prince John, bends the rules to rob from the rich (mostly evil) and give to the poor (mostly good), Jack and the Bean Stock, who made an improbable deal and ended up with the giant's treasure, etc. All of these fairy tales are reinforced with a variety of stories of people who "got rich quick". There are also the lottery winners, the average person who suddenly inherited a fortune from a distant relative, the overnight dot.com millionaires. The myth of income mobility has always exceeded reality but rags-to-riches stories are expressed through a number of cultural carriers. At a certain level, it may be the invocation of elements of these archetypal stories - the rich and evil despot whose ill-gotten gains are going to be shared, the wealthy philanthropist who wants to do good, the oppressed businessman or farmer who just wants to get what is rightfully his - which lead some people to believe that "it could happen to them".

\section{CONSTRUCTED FEAR}

During the last decades, fear as an emotion has been an interesting topic for social scientists, who have taken a look at it in different ways and from different perspectives. Parrott (2001) defined fear as depending on two characteristics: fear caused by horror provoked by a scene or situation and fear derived from a nervousness process. In the first case, it is generated through alarm, shock, fright, terror, panic hysteria and mortification. In the second case, it is generated by anxiety, tenseness, uneasiness, apprehension, worry, distress and dread.

In our spam e-mails and fairy tales, we have found both types of fear: spam uses them to meet their ultimate goal and fairy tales are, in fact, a tool for helping children face some of them. Fear of death, for example, is one of the most common fears across cultures. It is somehow present in most spam female narratives: from the pain caused by the father's death to the anxiety for the consequences of the stepmother's abuse, a certain range of expressions of fear can be found.

Bauman (2006) has studied the issue of fear in our contemporaneous society, through his "liquid" conception. This liquid fear is expanded by means of information media that share speed as a transmission medium of this emotion. Internet is one this media, and it is easy to understand how, through the case we have just presented, it is possible that this fear is perceived and spread thanks to these persuasive mechanisms that senders of these e-mails know very well how to manage. Zimbardo 
(2007), also allows us, from a psychosocial perspective, to understand how these mechanisms to establish fears in society are so attractive and productive so as to act in a certain way on the subjetivization processes of individuals (or readers, such as in our case). "Lucifer's effect" is the thing that the princesses/ogres in our narratives have in common. It is an effect that has just one objective, getting money from the naïve reader.

As we have said, the purpose of these e-mails is getting money in a fraudulent way, and they achieve it by instilling fear in their readers. This fear means power (since the writers get, sometimes, the money they want) and control (since it allows people to act in a certain way).

\section{ReSULTS AND DISCUSSION}

Our analysis suggests, firstly, that spam e-mail narratives use fear as a mechanism for evoking some feelings on the recipient, in order to deceive them and impel them to act and, secondly, that the "secret message" of not trusting and being afraid mentioned by Eco (2012) is also present in these narratives, as a key part of the strategy used for establishing some kind of intimacy between the author and the recipient.

On the one side, the sender can be presented as fearful because of a series of terrible events that leave her (most of the times, the main character will be a woman) in a risky situation. Some other factors, as gender or ethnicity, or even using parts of an authority discourse, will contribute to evoking a mental frame in the recipient, in which he/she will be the hero - or a "magical assistant" to the main character, in any case, the only one able to help the weak and life-beaten maid. Fear is used here to appeal to empathy and mercy.

On the other side, the sender can present a situation in which the recipient is the only one who can, not only rescue the locked "princess", but also get a generous reward, that is, get the "Pot of Gold". This story may seem very simple, so the discourse of an authority is needed here: that is why the sender is a professional such as a policeman. But, as a result of this very narrative, the recipients can find themselves in a risky situation, involved in something dangerous and illegal, and this may cause some fear in him/her. So, the sender does the only thing that can be done: provide the recipient with the steps that need to be taken and guarantee the achievement of the goal if they are taken correctly, that is, obtaining the reward. Here, fear is not used to appeal to a feeling but to avoid it, in order for the sender to appeal to the recipient's greed.

As we have demonstrated, rewards, princesses, villains (stepmothers, especially) and heroes appear in these narratives, giving the recipient an 
interpretation framework that will made him/her impersonate the shrewd and courageous hero that saves the damsel in distress and gets an economic reward for it.

Gender stereotypes are very present here, as they are in fairy tales, giving the female characters a weak - or wicked, if we talk about the stepmother - nature, and the male characters an authoritarian one.

Also, the ability to deceive through these spam e-mails has a lot of things to do with fake and hidden identities. When anonymity is a synonym of distrust and fear, it can act as a Foucauldian control/power mechanism that makes it possible for these e-mails to, sometimes, achieve their goals. As Foucault (1965) suggests, society acts according to certain power and control mechanisms that, most of the times, are virtual and non-material. The fear that these e-mails can cause in their readers is, in many cases, the same fear that individuals can perceive in their daily tasks. It is an intimacy process that allows the reader to feel and listen to emotions from someone who is suffering or who is in a dangerous situation, even if fictitious. This kind of empathy allows us to feel dangers that are very far from our daily tasks, but that we can imagine and perceive as real.

Every technological innovation has its negative, fraudulent or damaging aspects for the users, and spam e-mails are just one example. An information and communication medium such as electronic e-mails finds in Spam its damaging and "evil" practice.

In our daily practices, we have to learn how to deal with these fears, trying to construct and de-construct through a critical analysis (just as the one we proposed), or through a good anti-virus that filters these kind of e-mails.

Definitely, believing in spam is like believing in fairy tales, and, even if it may seem to be too naïve, most users are susceptible to fall into this trap. Long ago learnt gender stereotypes as well as our childish fears stay with us during adulthood and some people learn how to evoke them, to deceive others by using certain mechanisms to bring them back, in order to meet their goals: getting people's money. That is why we decided to make this parallelism between spam and fairy tales, and that is why we suggest that Internet users pay a little more attention when reading these ingeniously written narratives.

\section{BIBLIOGRAPHICAL REFERENCES}

Albrecht, T., Burleson, B., \& Goldsmith, D., 1994, “Supportive communication", in Mary L. Knapp \& George Miller (Eds.), Handbook 
of interpersonal communication, Sage, Thousand Oaks, CA, pp.419449.

Bauman, Z., 2006, Liquid fear, Polity Press, London.

Beldad, A., De Jong, M., \& Steehouder, M., 2010, "How shall I trust the faceless and the intangible? A literature review on the antecedents of online trust",in Computers in Human Behavior,26(5), pp. 857-869.

Bruner, J., 1990, Acts of meaning, Harvard University Press, Harvard.

Cukier, W.,Nesselroth, E., \& Cody, S., 2007,Genre, Narrative and the Nigerian Letter in Electronic Mail.In40th Hawaii International Conference on Systems Science (HICSS-40 2007), CD-ROM / Abstracts Proceedings, 3-6 January 2007, Waikoloa, Big Island, HI, USA.

Eco, U., 2012, Vi avviso che sono morto, ma è falso. L'Espresso, Torino.

Fisher, W., 1987, Human communication as narration: Toward a philosophy of reason, value, and action, University of South Carolina Press, Columbia, SC.

Foucault, M. 1965, Madness and civilization, Random House, New York.

Heider,F., 1958, The psychology of interpersonal relations, Wiley, New York.

Holmes, J., \& Meyerhoff, M., 2003, The Handbook of Language and Gender, Blackwell Publishing, London.

Koenig Kellas, J., Willer, E., \& Kranstuber, H., 2011, “Fairytales and tragedies: Narratively making sense of the dark side (and the dark side of making sense) of personal relationships", in W. Cupach and B. Spitzberg (Eds.) The dark side of close relationships II, Routledge, New York, pp.63-94.

Lakoff, G., 1992, "The contemporary theory of metaphor", in O. Andrew, (ed.) Metaphor and Thought, Cambridge University Press, Cambridge.

McAdams, D., 1993, The stories we live by: Personal myths and the making of the self, The Guilford Press, New York.

Okri, B., 1997, A way of being free, Phoenix House, London.

Parrott, G., 2001, Emotions in Social Psychology, Psychology Press, Philadelphia

Propp, V., 1968, Morfología del cuento, University of Texas Press, Austin.

Tu, C., 2002b, "The measurement of social presence in an online learning environment", in International Journal on E-Learning, 1(2), pp-34-45. 
Tu, C., \& Mclsaac, M. 2002, "An examination of social presence to increase interaction in online classes", in American Journal of Distance Education, 16(2), 131-150.

Weber, A., Harvey, J., \& Stanley, M., 1987, "The nature and motivations of accounts for failed relationships", in R. Burnett, P. McGhee, \& D. Clark (eds.),Accounting for relationships, Methuen, London, pp.114-133.

Whitty, M., \& Joinson, A., 2009, Truth, lies and trust on the Internet, Routledge, New York.

Zimbardo, P., 2007, The Lucifer Effect, Under standing How good people turn evil, Random House, New York. 